\title{
Competitive sorption of molybdate and phosphate in Andisols
}

\author{
E.Vistoso ${ }^{1}$, B.K.G. Theng ${ }^{2}$, N.S. Bolan ${ }^{3}$, R.L. Parfitt ${ }^{2}$ and M.L. Mora ${ }^{4 *}$ \\ ${ }^{I}$ Instituto de Investigaciones Agropecuarias (INIA), Centro Regional de Investigación Agropecuaria Remehue \\ (INIA Remehue), P.O. Box 24-O, Osorno, Chile. ${ }^{2}$ Landcare Research, Private Bag 11052, Manawatu Mail \\ Centre, Palmerston North 4442, New Zealand. ${ }^{3}$ Centre for Environmental Risk Assessment, University of \\ South Australia, SA 5095, Australia. ${ }^{4 *}$ Center of Plant-Soil Interaction and Natural Resources Biotechnology, \\ Scientific and Technological Bioresource Nucleus (BIOREN), Universidad de La Frontera, Casilla 54-D, \\ Temuco,Chile.*Corresponding author:mariluz@ufro.cl
}

\begin{abstract}
We have examined the effects of both $\mathrm{pH}$ and phosphate concentrations on molybdate sorption by four Chilean Andisols with varying chemical properties. For both anions adsorption decreased with an increase in soil $\mathrm{pH}$ and also with organic matter content in the soils. In general, more phosphate than molybdate was sorbed by the soils. The Freundlich equation adequately described adsorption of both anions. Differences in the extent of sorption of molybdate and phosphate and in isotherm shape between soils were ascribed to variations in soil properties. The competitive sorption data were adequately described by the multicomponent Freundlich equations. Phosphate strongly competed with molybdate for sorption sites on the Andisols, causing molybdate sorption to decrease by $10-27 \%$. The competition coefficients for phosphate and molybdate sorption were variable, indicating that competition between the two anions was not symmetrical. The present results provide further evidence to indicate that the surfaces of Andisols are rich in reactive Al-OH and $\mathrm{Fe}-\mathrm{OH}$ groups, exposed at colloidal particle surfaces. Molybdate sorption appeared to be mainly associated with free Al- and Fe-oxides, while phosphate sorption was primarily regulated by $\mathrm{Al}$ - and Fe-humus complexes.
\end{abstract}

Keywords: Andisol, Competitive sorption, Molybdate, Phosphate, $\mathrm{pH}$ 


\section{Introduction}

The majority of Chilean forestry, agriculture, and livestock are developed on soils derived from volcanic ash, occupying about $2264 \mathrm{~km}^{2}$. Andisols account for $65 \%$ of the country's land surface, and differ from other mineral soils in their physical, chemical and biological properties which, in turn, determine their agronomical use and management. The mineralogical composition of Andisols is dominated by poorly crystalline minerals such as allophane with variable (pH-dependent) charge. From an agricultural standpoint, these soils have many favorable characteristics, including good physical structure, high organic matter content and water holding capacity, and low bulk density. However the high $\mathrm{P}$ retention and soluble $\mathrm{Al}$ content may affect agriculture production (Mora et al. 2006).

In order to determine the anion nutrient availability in Andisols we studied the anion sorption (Mora et al, 2005), and competition between selenite and phosphate (Barrow et al., 2005), and sulphate and phosphate (Jara et al, 2006) adsorption. According previous studies (Vistoso et al., 2009; Lopez et al., 2007), P strongly compete with Mo for active sites, thereby increasing Mo availability in Andisols. Molybdenum (Mo) is an essential micronutrient for plant growth, although in high concentrations it can be toxic for livestock. Molybdate ion $\left(\mathrm{MoO}_{4}^{2-}\right)$ is the major Mo species in soil solutions and the principal form of Mo that plant roots absorb.

The high anion retention capacity of Andisols affects the mobility and bioavailability of anions such as phosphate and molybdate, thereby resulting in the low efficiency of phosphate and molybdate fertilizers in these soils (Ribera et al., 2010). The relationship between different soil properties and phosphate sorption capacity of Andisols has been extensively investigated (Bolan \& Barrow, 1984; Barrow, 1985; Parfitt, 1989) but less information with respect to molybdate sorption. Our preliminary results (Vistoso, 2005; Vistoso et al., 2009) suggest that the mineralogical composition and organic matter content of the Andisols control the kinetics of the sorption of both molybdate and phosphate. Molybdate appeared to have a high affinity for Fe- and Al-oxides, while phosphate was largely sorbed to Fe-and Al-humus complexes and clay minerals (allophane and ferrihydrite).

The relationship between phosphate and molybdate bioavailability in Andisols was reported by Lopez et al. (2007) and Ribera et al. (2010). Although phosphate is known to be a more effective competitor than molybdate (Theng, 1971; Barrow, 1992), no models describing competitive sorption between phosphate and molybdate have so far been developed.

Here we use the multicomponent Freundlich equations modified by Barrow et al. (2005), based on competitive sorption of binary solute mixtures, to describe molybdate-phosphate competition in Chilean Andisols. Sorption of molybdate is treated as analogous to that of phosphate with both anions competing for the same sorption sites. To this end, we examined: i) the effect of $\mathrm{pH}$ on phosphate and molybdate sorption by some Andisols from Southern Chile, and ii) the effect of phosphate on molybdate sorption by Andisols varying in anion sorption capacity.

\section{Materials and methods}

\subsection{Soil collection}

Surface samples (0-20 cm depth) of four Andisols (Vilcún, Entic Dystrandept; Pemehue, Hydric Dystrandept; Osorno, Typic Dystrandept and Piedras Negras, Typic Dystrandept) were collected between $37^{\circ}$ $35^{\prime}-44^{\circ} 04^{\prime}$ latitude south and $70^{\circ} 50^{\prime}-71^{\circ} 35^{\prime}$ ' longitude west in Southern Chile. The soils were selected for their contrasting chemical properties and Mo availability to plants. Bulk samples were air-dried, crushed and passed through a $2 \mathrm{~mm}$ sieve. 


\subsection{Physical-chemical characterization of soils}

The chemical characteristics of the soil samples were determined according to the methodology modified by Sadzawka et al. (2006). Soil pH was measured potentiometrically in water using soil suspensions at a soil:solution ratio of 1:2.5. Organic matter was estimated by wet digestion using a modified Walkley-Black method. Exchangeable base cations $(\mathrm{Ca}, \mathrm{Mg}, \mathrm{K}, \mathrm{Na})$ and exchangeable aluminium were extracted with $1 \mathrm{M}$ $\mathrm{NH}_{4}$-acetate at $\mathrm{pH} 7.0$ and $1 \mathrm{M} \mathrm{KCl}$, respectively, and analyzed using atomic absorption spectrophotometry (AAS). Phosphate and sulphate were extracted with 0.5
$\mathrm{M} \mathrm{NaHCO}_{3}$ at $\mathrm{pH} 8.5$ and $1 \mathrm{M} \mathrm{Ca}\left(\mathrm{H}_{2} \mathrm{PO}_{4}\right)_{2}$, respectively. Exchangeable Mo was extracted with ammonium bicarbonate diethylene triamine pentacetic acid (AB-DTPA) (Soltanpour, 1991), while total Mo was extracted with $\mathrm{HNO}_{3}$ and $\mathrm{H}_{2} \mathrm{O}_{2}$ (Edgell, 1988). Both exchangeable and total Mo were analyzed using graphite furnace atomic absorption spectrometry (GFAAS). The total specific surface area (SSA) was measured by sorption of ethylene glycol monoethyl ether (EGME) (Heilman et al., 1965), while the number of active sites $\left(\mathrm{N}_{\mathrm{s}}\right)$ for anion sorption was measured by distillation with $1 \mathrm{M}$ Ca-acetate (Holtzclaw \& Sposito, 1979). The physicochemical characteristics of the soils are listed in Table 1.

Table 1. Physico-chemical characteristics of soils.

\begin{tabular}{|c|c|c|c|c|}
\hline Parameters & Vilcún & Pemehue & Osorno & P. Negras \\
\hline Soil classification a & Entic Dystrandept & Hydric Dystrandept & t Typic Dystrandept & Typic Dystrandept \\
\hline $\operatorname{SSA}\left(\mathrm{m}^{2} / \mathrm{g}\right)^{\mathrm{b}}$ & $161.59 \pm 1.84$ & $166.10 \pm 1.65$ & $149.95 \pm 1.50$ & $120.26 \pm 1.72$ \\
\hline $\mathrm{N}_{\mathrm{s}}\left(\mathrm{cmol}(-) \mathrm{kg}^{-1}\right)^{\mathrm{c}}$ & $30.45 \pm 0.75$ & $36.62 \pm 0.94$ & $70.00 \pm 0.57$ & $58.63 \pm 0.82$ \\
\hline $\mathrm{pH}$ water $^{\mathrm{d}}$ & $5.47 \pm 0.01$ & $5.41 \pm 0.06$ & $4.81 \pm 0.02$ & $5.40 \pm 0.02$ \\
\hline Organic matter $\left(\mathrm{g} \mathrm{kg}^{-1}\right)^{\mathrm{d}}$ & $140 \pm 1.26$ & $150 \pm 0.58$ & $210 \pm 1.16$ & $240 \pm 1.41$ \\
\hline $\mathrm{S}\left(\mathrm{mg} \mathrm{kg}^{-1}\right)^{\mathrm{d}}$ & $10 \pm 0.64$ & $7 \pm 0.42$ & $20 \pm 0.58$ & $10 \pm 0.25$ \\
\hline$P\left(m g k g^{-1}\right)^{d}$ & $13 \pm 0.76$ & $6 \pm 0.62$ & $24 \pm 0.30$ & $5 \pm 0.15$ \\
\hline $\mathrm{Al}\left(\mathrm{cmol}(+) \mathrm{kg}^{-1}\right)^{\mathrm{d}}$ & $0.24 \pm 0.01$ & $0.22 \pm 0.05$ & $0.98 \pm 0.02$ & $0.30 \pm 0.04$ \\
\hline$\Sigma$ cations $\left(\mathrm{cmol}(+) \mathrm{kg}^{-1}\right)^{\mathrm{d}}$ & $8.89 \pm 0.11$ & $4.89 \pm 0.13$ & $4.30 \pm 0.18$ & $3.04 \pm 0.16$ \\
\hline $\mathrm{Al}$ saturation $(\%)^{\mathrm{d}}$ & $2.63 \pm 0.17$ & $4.31 \pm 0.18$ & $18.56 \pm 0.84$ & $8.98 \pm 0.13$ \\
\hline Extractable $\mathrm{Al}\left(\mathrm{mg} \mathrm{kg}^{-1}\right)^{\mathrm{d}}$ & $600 \pm 11.67$ & $1100 \pm 15.44$ & $1473 \pm 35.69$ & $1876 \pm 16.74$ \\
\hline Exchangeable Mo $\left(\mathrm{mg} \mathrm{kg}^{-1}\right)^{\mathrm{e}}$ & $0.009 \pm 0.001$ & $0.010 \pm 0.001$ & $0.016 \pm 0.002$ & $0.022 \pm 0.003$ \\
\hline Total Mo $\left(\mathrm{mg} \mathrm{kg}^{-1}\right)^{\mathrm{f}}$ & $0.22 \pm 0.01$ & $0.48 \pm 0.03$ & $0.56 \pm 0.04$ & $0.76 \pm 0.05$ \\
\hline
\end{tabular}

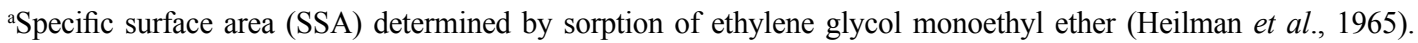
${ }^{b}$ Number of active sites $\left(\mathrm{N}_{\mathrm{s}}\right)$ determined according to methodology described by Holtzclaw and Sposito (1979). ${ }^{\mathrm{c}} \mathrm{De}$ -

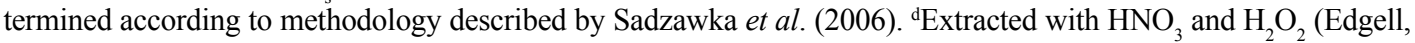
1988). ${ }^{~}$ Extracted with ammonium bi-carbonate diethylene triamine pentacetic acid, AB-DTPA (Soltanpour, 1991).

\subsection{Molybdate and phosphate sorption isotherms}

The sorption isotherms for phosphate and molybdate were obtained from batch experiments using a soil:solution ratio of 1:20 with $0.1 \mathrm{M} \mathrm{KCl}$ as back- ground electrolyte. Single species sorption was measured at initial $\mathrm{pH}$ values of 4.0, 5.0 and 6.0, adjusted by adding dilute $\mathrm{HCl}$ or $\mathrm{KOH}$ solution to the soil suspensions in an $\mathrm{N}_{2}$ environment so as to eliminate $\mathrm{CO}_{2}$. The initial molybdate $\left(\mathrm{Na}_{2} \mathrm{MoO}_{4} \cdot 2 \mathrm{H}_{2} \mathrm{O}\right)$ and 
phosphate $\left(\mathrm{K}_{2} \mathrm{HPO}_{4}\right)$ concentrations varied between 0 and $5.0 \mathrm{mmol} \mathrm{L}^{-1}$.

Duplicate samples were weighed and placed in polypropylene centrifuge tubes, and the suspensions were shaken in an end-over-end shaker for $24 \mathrm{~h}$ at 298 $\mathrm{K}$. The $\mathrm{pH}$ of the suspensions was measured immediately thereafter. The soil suspensions were then centrifuged at $10000 \mathrm{~g}$ for 10 minutes and aliquots of the supernatants were taken for analysis. Mo was determined by AAS and $\mathrm{P}$ by the phosphomolybdate-ascorbic acid method (Sadzawka et al. 2006). The amount of anion sorbed was derived from the difference between the initial and final solution concentrations.

\subsection{Molybdate and phosphate competitive sorption isotherms}

The competitive sorption isotherms for phosphate and molybdate were obtained in batch systems using a soil:solution ratio of 1:20 with $0.1 \mathrm{M} \mathrm{KCl}$ as background electrolyte at an initial $\mathrm{pH}$ of 5.0. For the competitive sorption studies the initial molybdate $\left(\mathrm{Na}_{2} \mathrm{MoO}_{4} \cdot 2 \mathrm{H}_{2} \mathrm{O}\right)$ concentrations were: $0,0.25,0.50$, $0.75,1.0,1.5,2.0,2.5,3.0,3.5,4.0,4.5$ and $5.0 \mathrm{mmol}$ $\mathrm{L}^{-1}$, and each of these concentrations were tested with 0 , $0.5,1.0$ and $2.0 \mathrm{mmol} \mathrm{L}^{-1}$ phosphate $\left(\mathrm{K}_{2} \mathrm{HPO}_{4}\right)$. Duplicate samples were weighed and placed in polypropylene centrifuge tubes, and the suspensions were shaken in an end-over-end shaker for $24 \mathrm{~h}$ at $298 \mathrm{~K}$. Suspension $\mathrm{pH}$ and the concentrations of Mo and $\mathrm{P}$ in the supernatant solutions were determined as described above.

\subsection{Mathematical sorption modelling}

Single species molybdate and phosphate sorption data at different soil $\mathrm{pH}$ levels $(\mathrm{n}=4)$ were fitted to the Freundlich equation (Eq. 1):

$$
X=a C^{(1 / b)}
$$

where $X$ is the amount of anion sorbed $\left(\mathrm{mmol} \mathrm{kg}^{-1}\right)$; $C$ is the equilibrium anion concentration $\left(\mathrm{mmol} \mathrm{L}^{-1}\right)$, and $a$ and $b$ are constants.

The competitive sorption data for Mo and $\mathrm{P}$ for each of the four soils were fitted to the multicomponent Freundlich equations (Eqs. 2 and 3) using a computer program, Model 2 modified for the competitive sorption of Mo and P, (Barrow et al., 2005):

$$
\begin{aligned}
& S_{\mathrm{Mo}}=a_{\mathrm{Mo}} C_{\mathrm{Mo}} /\left(C_{\mathrm{Mo}}+K_{\mathrm{Mo}, \mathrm{P}} C_{\mathrm{P}}\right)^{1-b \mathrm{Mo}} \\
& S_{\mathrm{P}}=a_{\mathrm{P}} C_{\mathrm{P}} /\left(C_{\mathrm{P}}+K_{\mathrm{P}, \mathrm{Mo}} C_{\mathrm{Mo}}\right)^{1-b \mathrm{P}}
\end{aligned}
$$

where $S_{M o}$ is the amount of Mo sorbed per unit mass of sorbent in the presence of competitor $\mathrm{P}$, and $S_{P}$ is the amount of $\mathrm{P}$ sorbed per unit mass of sorbent in the presence of competitor Mo; $a_{M o}$ and $a_{P}$ are the singlesolute Freundlich constants for solutes Mo and P; $C_{M o}$ and $C_{P}$ are the equilibrium concentrations - ideally activities - of the solutes; $K_{M o, P}$ is the competition coefficient of $\mathrm{P}$ on Mo; and $K_{P, M o}$ is the competition coefficient of Mo on P. According to Barrow et al. (2005), molybdate-phosphate competition was not symmetrical. Furthermore, the process involved not only competition for sorption sites but also electrical potential effects following penetration of the adsorbent's structure by the solute.

Sorption was calculated from the observed change in solution concentration. Sorption and solution concentration are therefore not independent variables. This problem was circumvented by regarding the above sorption equations as simultaneous with the equation used to calculate sorption from the observed change in concentration. For any set of parameters, a simultaneous result was found by iteration using the computer program. This allowed the final equilibrium concentration to be predicted for each initial concentration. A sim- 
ple routine was then used to find the sets of parameters that minimized the residual sum of squares of the difference between observed and predicted equilibrium concentrations.

\subsection{Statistical analysis}

The experimental data were statistically analyzed using SPSS version 13. The fit of each mathematical sorption model was evaluated by determining the coefficient $\left(\mathrm{R}^{2}\right)$ and standard error (SE) and used to compare the applicability of the different models at a confidence level of $95 \%$.

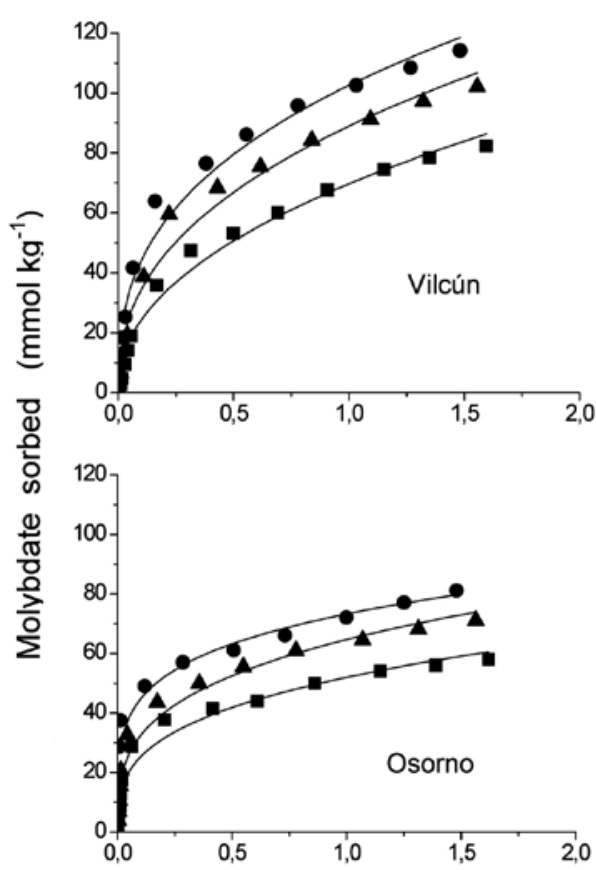

Molybdate in solution $\left(\mathrm{mmol} \mathrm{L}^{-1}\right)$

\section{Results and Discussion}

\subsection{Effect of $p H$ on molybdate and phosphate sorption}

The sorption isotherms for both anions as a function of $\mathrm{pH}$ are presented in Figures 1 and 2. For both anions, sorption decreased with an increase of $\mathrm{pH}$ in suspension. At any given $\mathrm{pH}$ and solution concentration, more phosphate than molybdate was sorbed by all Andisols except for the Vilcún soil.
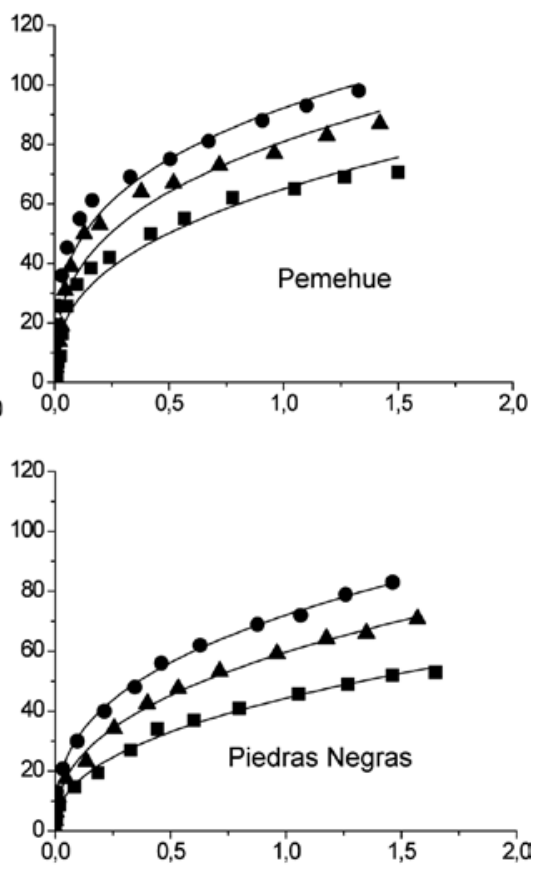

Figure 1. Effect of initial $\mathrm{pH}$ on molybdate sorption by Vilcún, Pemehue, Osorno and Piedras Negras soils $(\bullet \mathrm{pH} 4.0 ; \boldsymbol{\Delta} \mathrm{pH}$ 5.0; $\bullet \mathrm{pH}$ 6.0: Experimental data; —: Model 2 fitted lines). 


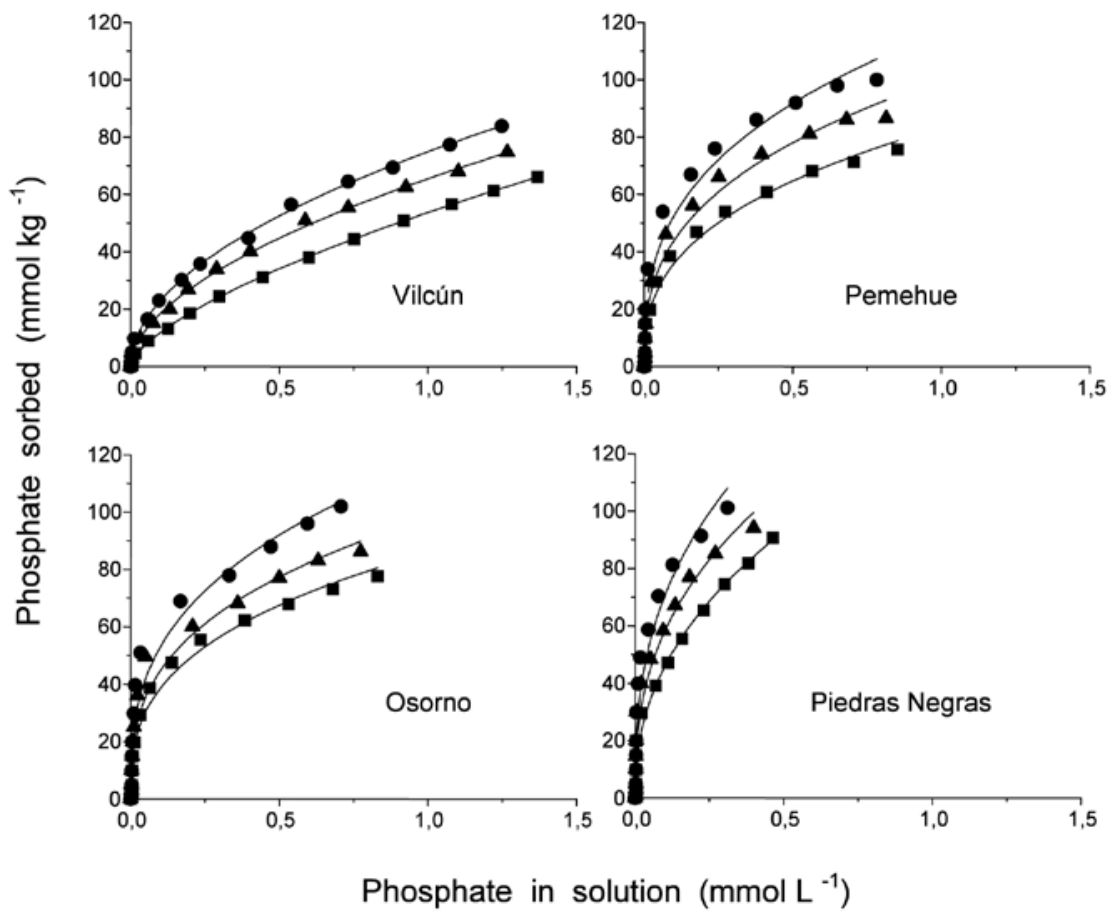

Figure 2. Effect of initial $\mathrm{pH}$ on phosphate sorption by Vilcún, Pemehue, Osorno and Piedras Negras soils (• $\mathrm{pH}$ 4.0; $\boldsymbol{\mathrm { pH }}$ 5.0; $\bullet \mathrm{pH}$ 6.0: Experimental data; —: Model 2 fitted lines).

Taking sorption at $\mathrm{pH} 4.0$ as $100 \%$, molybdate sorption decreased by $12 \%$ at $\mathrm{pH} 5.0$ and $26 \%$ at $\mathrm{pH} 6.0$, while phosphate sorption decreased by $16 \%$ at $\mathrm{pH} 5.0$ and $32 \%$ at $\mathrm{pH}$ 6.0. Similarly, Goldberg et al. (2008) and Goldberg et al. (2009) noted a marked decrease in $\mathrm{P}$ and Mo sorption by oxides and volcanic soils at $\mathrm{pH}>5.0$, ascribed to differences in the origin, mineral composition, and degree of development of the soils.

For both anions, the initial slope of the isotherms depends on solute concentration. The curves also indicate a high anion-surface affinity. The isotherms for molybdate sorption tend to be of the L-type (Giles et al., 1974), indicating that the number of high affinity sites diminishes as sorption progresses. Less molybdate was sorbed by the Vilcún and Pemehue soils than by the Osorno and P. Negras soils, consistent with the lower number of active sites $\left(\mathrm{N}_{\mathrm{s}}\right)$ determined for the former two soils (Table 1). On the other hand, the phosphate sorption isotherms tend to be of the Htype, indicating high anion-surface affinity especially for the Osorno and P. Negras soils. These two soils also have a relatively large number of active sites although their specific surface areas (SSA) are smaller than those of the Vilcún and Pemehue soils.

For all the Andisols used except Vilcún, the extent of molybdate sorption was $20 \%$ lower than that of phosphate (Figures 1 and 2). Molybdate sorption was accompanied by liberation of hydroxyl ions into the soil solution, increasing the supernatant $\mathrm{pH}$ by up to one unit. The decrease in molybdate sorption in the 
presence of phosphate may be attributed to the two factors that include steric hindrance and electrostatic repulsion; these factors might be expected to cause the difference in sorption behaviour of molybdate by these Andisols, relative to phosphate.

Barrow (1970) found that the depressing effect of increased $\mathrm{pH}$ on molybdate sorption was about 20 times greater than for phosphate. The difference between our and Barrow's (1970) observation may arise because we used $0.1 \mathrm{M} \mathrm{KCl}$, whereas Barrow (1970) used $0.01 \mathrm{M} \mathrm{CaCl}_{2}$. The decrease in electric potential with increasing $\mathrm{pH}$ is less in a calcium system than in a potassium one. On the other hand, Golberg et al. (2009) reported that Mo sorption from $\mathrm{pH} 4.0$ to 8.0 by a range of soils was independent ionic strength.
The observed increase in supernatant $\mathrm{pH}$ due to Mo sorption (Figure 3a) clearly indicates that the underlying mechanism is one of ligand exchange between molybdate ions in solution and surface hydroxyl groups, similar to that proposed for phosphate (Goldberg \& Sposito, 1985; Parfitt, 1989; Goldberg et al., 2008; Vistoso, 2005; Vistoso et al., 2009). As a result, the net negative surface charge would increase (Bolan \& Barrow, 1984; Bolan et al., 1986; Theng et al., 2005), while the sorption capacity of the soils for both $\mathrm{P}$ and Mo anions would decrease (Figures 1 and 2). Similar behaviour is observed with increasing supernatant $\mathrm{pH}$ due to competitive sorption of molybdate in the presence of phosphate for all the Andisols (Figure 3b), in agree with Goldberg \& Forster (1998).
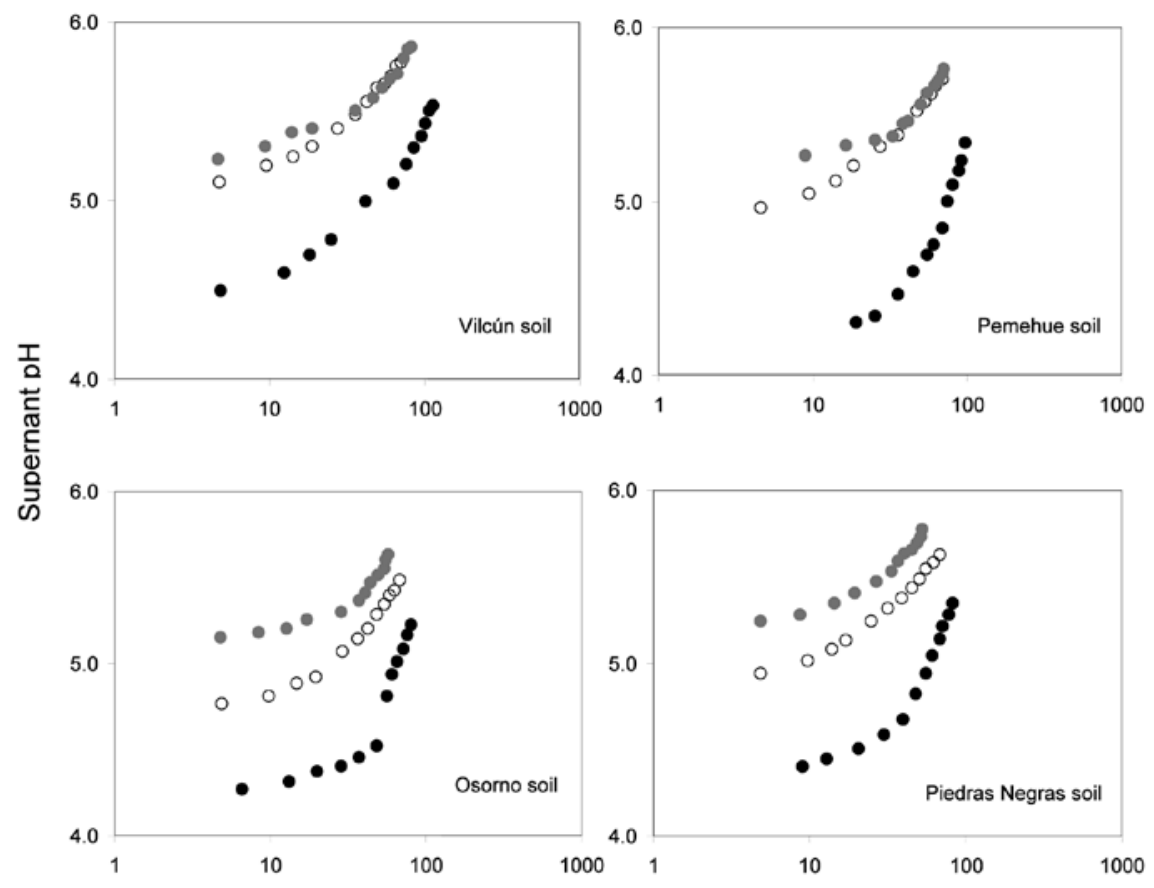

Molybdate sorption (log)

Figure 3a. Relationship between supernant $\mathrm{pH}$ and molybdate sorbed by Vilcún, Pemehue, Osorno and Piedras Negras soils at different initial $\mathrm{pH}$ levels (• $\mathrm{pH} 4.0 ; \circ \mathrm{pH} 5.0 ; \bullet \mathrm{pH} 6.0)$. 

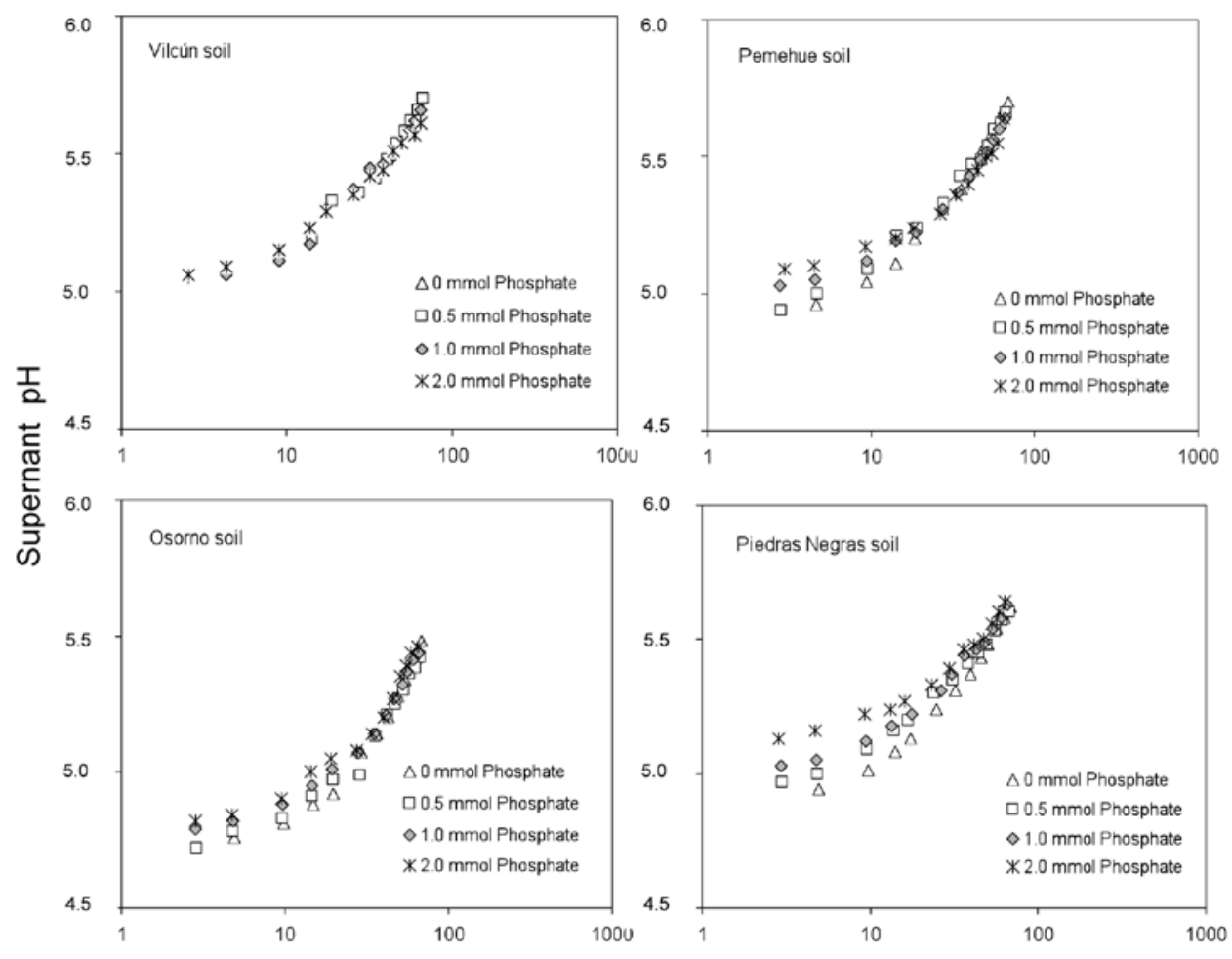

\section{Molybdate sorption (log)}

Figure 3b. Relationship between supernant $\mathrm{pH}$ and molybdate sorbed in presence of different concentration of phosphate by Vilcún, Pemehue, Osorno and Piedras Negras soils at initial pH 5.0.

The experimental data for both anions were adequately modelled using the Freundlich equation (Figures 1 and 2) with $R^{2}>0.921$ (Table 2). For the Andisols used, the sorption parameters indicate that both the sorption capacity $(a)$, and sorption energy $(b)$ for phosphate are greater than that for molybdate except for the Vilcún soil. Both parameters decreased in magnitude as sorption declined with rising $\mathrm{pH}$ (Table 2). 
Table 2. Freundlich isotherm parameters for molybdate and phosphate sorption at different initial $\mathrm{pH}$ values.

\begin{tabular}{|c|c|c|c|c|c|c|c|c|c|}
\hline \multirow{3}{*}{ Soil } & \multicolumn{3}{|c|}{$\mathrm{pH} 4.0$} & \multicolumn{3}{|c|}{ pH 5.0} & \multicolumn{3}{|c|}{ pH 6.0} \\
\hline & \multicolumn{9}{|c|}{ Parameters $\left(\mathrm{mmol} \mathrm{kg}^{-1}\right)$} \\
\hline & $a$ & $\boldsymbol{b}$ & $\mathbf{R}^{2}$ & $a$ & $b$ & $\mathbf{R}^{2}$ & $a$ & $b$ & $\mathbf{R}^{2}$ \\
\hline & \multicolumn{9}{|c|}{ Molybdate } \\
\hline Vilcún & 102.56 & 0.366 & 0.983 & 88.95 & 0.411 & 0.980 & 69.66 & 0.459 & 0.982 \\
\hline Pemehue & 92.26 & 0.298 & 0.966 & 80.94 & 0.339 & 0.951 & 65.03 & 0.373 & 0.951 \\
\hline Osorno & 73.25 & 0.213 & 0.984 & 64.63 & 0.299 & 0.971 & 52.00 & 0.313 & 0.964 \\
\hline \multirow[t]{2}{*}{ P. Negras } & 72.03 & 0.359 & 0.997 & 59.65 & 0.399 & 0.996 & 44.30 & 0.424 & 0.995 \\
\hline & \multicolumn{9}{|c|}{ Phosphate } \\
\hline Vilcún & 74.87 & 0.512 & 0.998 & 65.45 & 0.549 & 0.998 & 53.67 & 0.657 & 0.999 \\
\hline Pemehue & 116.70 & 0.347 & 0.963 & 100.01 & 0.358 & 0.972 & 83.45 & 0.367 & 0.979 \\
\hline Osorno & 116.69 & 0.342 & 0.946 & 97.97 & 0.341 & 0.948 & 85.97 & 0.348 & 0.971 \\
\hline P. Negras & 167.63 & 0.376 & 0.921 & 142.17 & 0.388 & 0.948 & 125.99 & 0.438 & 0.975 \\
\hline
\end{tabular}

These observations are consistent with those reported by Goldberg \& Forster (1998) and Barrow (1999) who showed that phosphate had a greater affinity than molybdate for a range of soils varying in $\mathrm{Fe}$ - and Al-oxide contents and $\mathrm{pH}$ levels. The present results also accord with those derived from kinetic measurements, using the same anions and soils (Vistoso et al., 2009).

In conclusion, the reactivity of molybdate toward the Andisols decreased in the following order: Vilcún $>$ Pemehue $>$ Osorno $>$ Piedras Negras. On the other hand, the reactivity of phosphate decreased in the opposite order: Piedras Negras $>$ Osorno $>$ Pemehue $>$ Vilcún. These results corroborate previous findings by Vistoso et al. (2009) that molybdate ion sorption affinity in the Vilcún and Pemehue soils was related to the content of free (dithionite-extractable) Al- and Fe-oxides (23.00 and $40.10 \mathrm{~g} \mathrm{~kg}^{-1}$ of $\mathrm{Al}_{\mathrm{d}}+\mathrm{Fe}_{\mathrm{d}}$, respectively). These workers further showed that phosphate availability in the Osorno and Piedras Negras soils was principally regulated by pyrophosphate-extract- able Al- and Fe-humus complexes (23.00 and $25.00 \mathrm{~g}$ $\mathrm{kg}^{-1}$ of $\mathrm{Al}_{\mathrm{p}}+\mathrm{Fe}_{\mathrm{p}}$, respectively), allophane and ferrihydrite. Likewise, Golberg et al. (2008) have suggested that Al- and Fe- oxides, clay minerals, organic matter, and allophane play an important role in molybdate sorption by mineral and volcanic ash soils.

\subsection{Effect of phosphate on molybdate sorption}

The analysis of competitive sorption indicated that molybdate sorption decreased by $10-27 \%$ in the presence of phosphate $\left(0.5-2.0 \mathrm{mmol} \mathrm{L}^{-1}\right)$ for all the Andisols (Figure 4). The reduction in molybdate sorption was greater at higher levels of phosphate addition, suggesting strong competition between the two anions. Previously, Lopez et al, (2007) showed in incubation studied the Mo availability increased by phosphate addition in Andisols. The phosphate-induced decrease in molybdate sorption was higher for the Pemehue and Piedras Negras soils than the Vilcún and Osorno soils (Figure 4). 


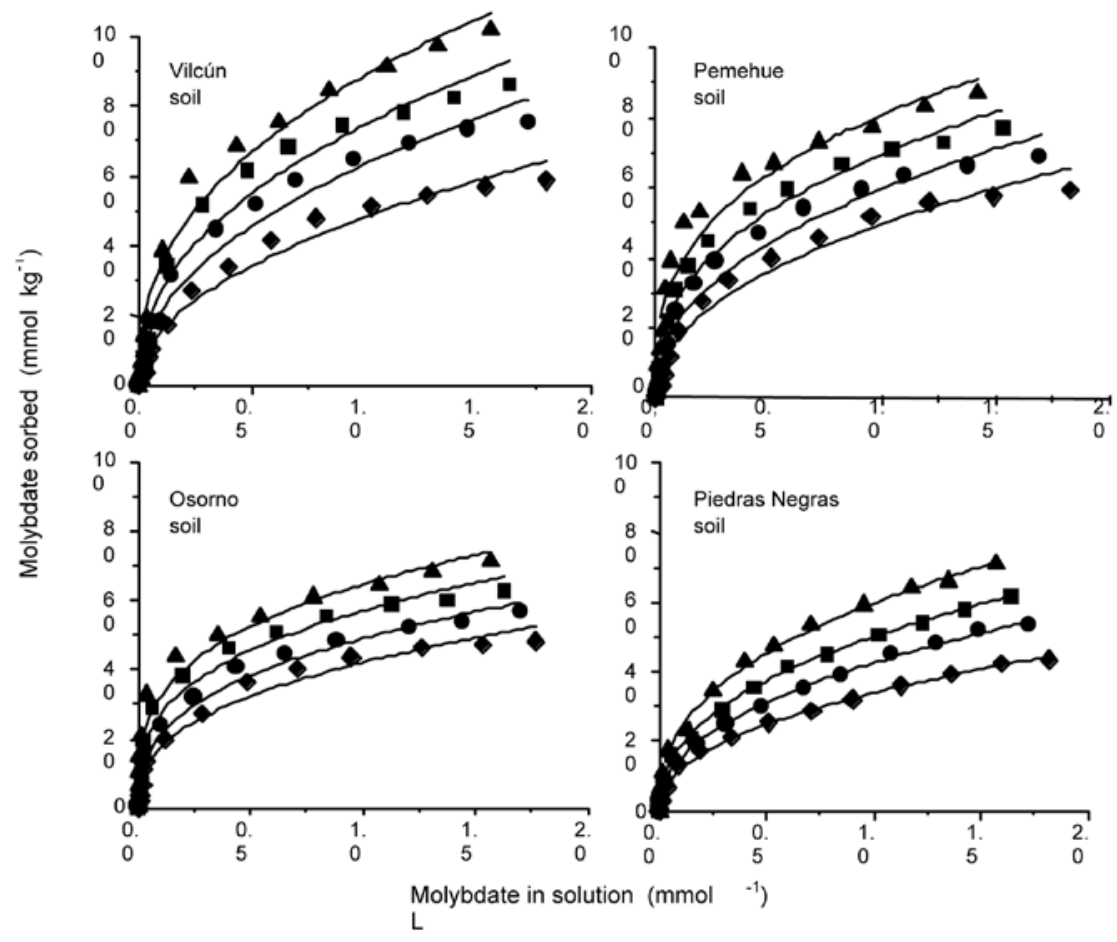

Figure 4. Competitive sorption of molybdate in presence of different concentrations of phosphate by Vilcún, Pemehue, Osorno and Piedras Negras soils (—:Model 2 modified lines; Experimental data: P1 ( $\mathbf{\Delta}$ ) 0 mM P, P2 (๘) $0.5 \mathrm{mM} \mathrm{P,} \mathrm{P3} \mathrm{( \bullet )} 1.0 \mathrm{mM} \mathrm{P,} \mathrm{P4} \mathrm{( \bullet )} 2.0 \mathrm{mM} \mathrm{P})$.

Competitive interactions between phosphate and molybdate indicated that at low molar ratios molybdate and phosphate compete for the same set of surface sites as reflected in a lower $K_{P, M o}$ (competition of Mo on P) and higher $K_{M o, P}$ (competition of $\mathrm{P}$ on Mo) coefficients. Further, the reduction in molybdate sorption was greater at higher levels of phosphate additions, suggesting strong competition in the Andisols used. Similarly, Xie \& McKenzie (1991) and Xu et al. (2006) observed that molybdate sorption to soils, goethite and pyrite was significantly reduced by the competitive sorption of phosphate.

At high concentrations phosphate was more effective in inhibiting molybdate sorption. This might be because sorption of phosphate by ligand exchange increased the net negative surface charge, enhancing electrostatic repulsion between molybdate and colloidal particle surface (Barrow, 1999; Barrow et al., 2005). These results are therefore contrary to those obtained by Roy et al. (1986) who suggested that phosphate and molybdate would continue to compete for the same surface sites at high phosphate concentrations.

The close fit of the competition data to the Freundlich equation, indicated by the $\mathrm{R}^{2}$ values of 0.947-0.996 for both molybdate and phosphate (Table 2), suggests the model can adequately describe molybdate sorption in the presence of added phos- 
phate. At the same time, the $K_{M o, P}$ and $K_{P, M o}$ values are indicative of non-symmetrical competition between Mo and P, rather than simple competition for sorption sites.

The ability of phosphate to out compete molybdate in these Andisols decreased in the order:
Pemehue $>$ Piedras Negras $>$ Vilcún $>$ Osorno. The coefficient values (Table 3 ) and Figure 5 show that phosphate sorption by the Andisols was not affected by different molybdate concentrations. By contrast, molybdate sorption was sensitive to the presence of phosphate (Figure 6 and Table 3).

Table 3. Parameters of the multicomponent Freundlich model fitted for competitive sorption between molybdate and phosphate in Andisols.

\begin{tabular}{|c|c|c|c|c|c|c|c|c|}
\hline \multirow{2}{*}{ Soil } & \multicolumn{8}{|c|}{ Parameters } \\
\hline & $a_{M o}$ & $a_{P}$ & $b_{M o}$ & $b_{P}$ & $K_{M o, P}$ & $K_{P, M o}$ & $\mathbf{R}^{2}{ }_{M_{0}}$ & $\mathbf{R}_{\mathbf{P}}^{2}$ \\
\hline Vilcún & 57.56 & 61.49 & 0.36 & 0.31 & 0.01 & 3.30 & 0.991 & 0.995 \\
\hline Pemehue & 60.69 & 82.78 & 0.31 & 0.43 & 0.03 & 6.03 & 0.947 & 0.994 \\
\hline Osorno & 57.43 & 85.34 & 0.29 & 0.44 & 0 & 2.85 & 0.996 & 0.995 \\
\hline P. Negras & 51.96 & 134.54 & 0.50 & 0.49 & 0.01 & 4.53 & 0.996 & 0.990 \\
\hline
\end{tabular}
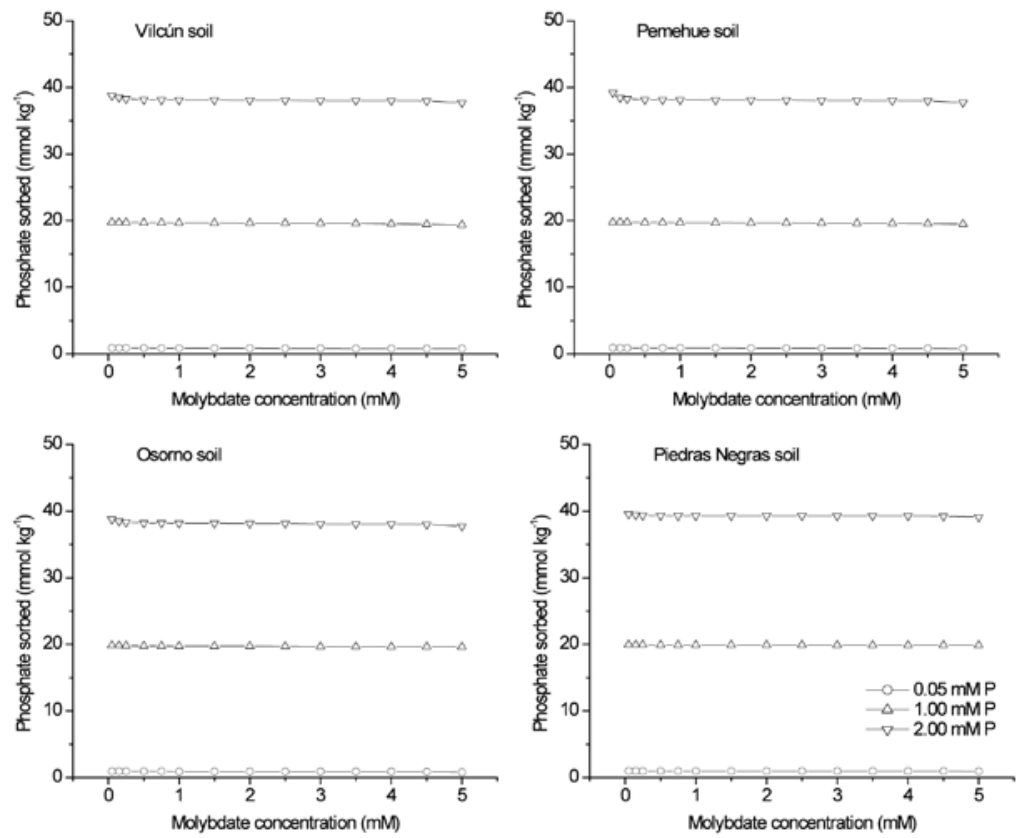

Figure 5. Effect of different molybdate concentrations on phosphate sorption by Vilcún, Pemehue, Osorno and Piedras Negras soils (०: $0.05 \mathrm{mM}$ P; $\triangle: 1.00 \mathrm{mM}$ P; $\nabla: 2.00 \mathrm{mM}$ P). 


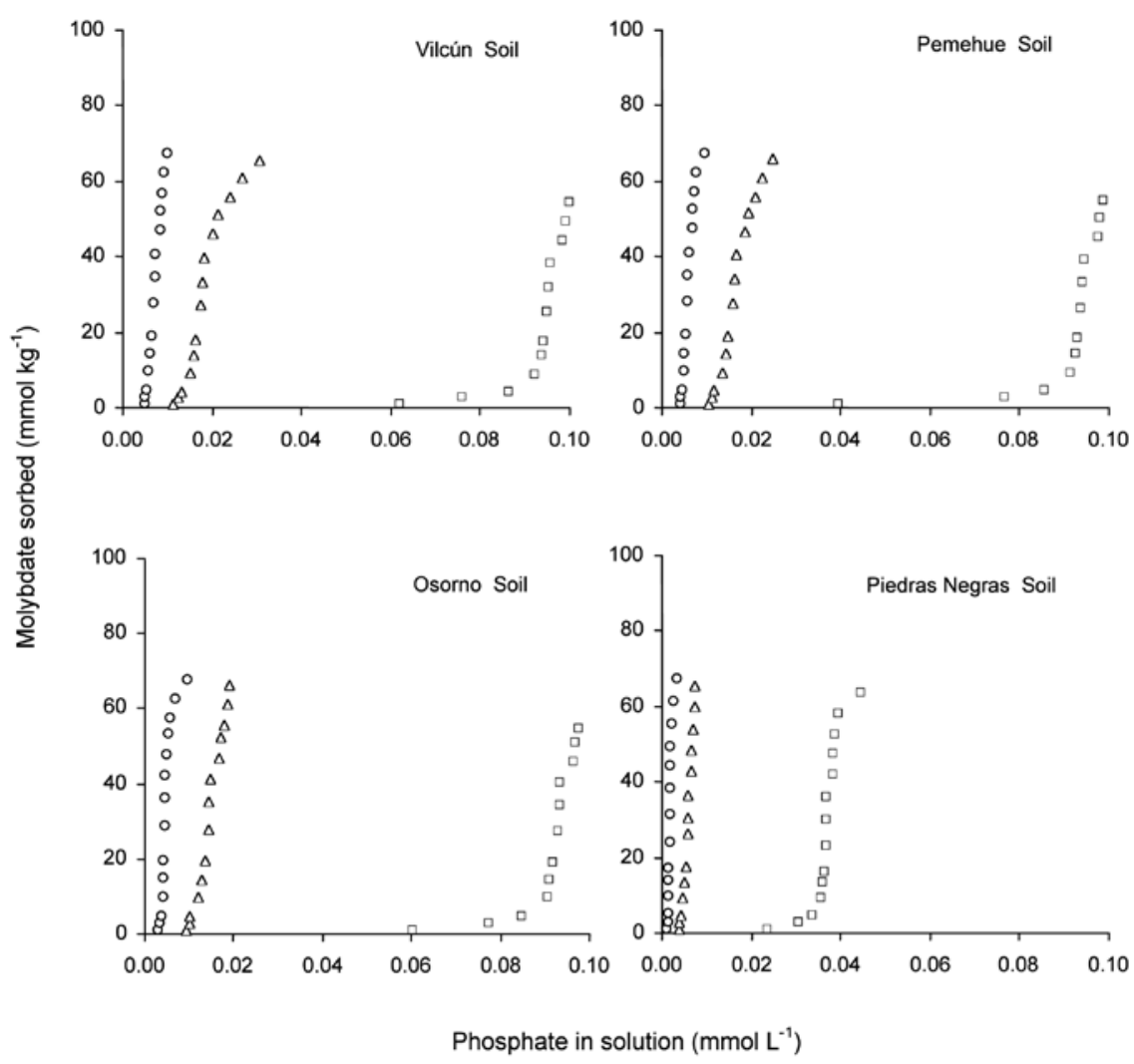

Figure 6. Effect of different phosphate concentrations on molybdate sorption by Vilcún, Pemehue, Osorno and Piedras Negras soils (०: $0.05 \mathrm{mM}$ P; $\triangle: 1.00 \mathrm{mM}$ P; $\square: 2.00 \mathrm{mM} \mathrm{P}$ ).

The superior ability of phosphate to compete against molybdate in the Andisols used may be explained in following terms: a) differences in the capacity of some soil components for sorbing phosphate and molybdate; b) since phosphate and molybdate are sorbed to similar surface sites and through a similar mechanism, increasing net negative surface charge, enhancing electrostatic repulsion between molybdate and colloidal particle; c) phosphate can access more surface sites than molybdate; d) phosphate and molybdate combined may be sorbed in greater amounts than each anion separately.

\section{Conclusions}

The sorption of molybdate and phosphate by some Chilean Andisols is sensitive to solution $\mathrm{pH}$ and may be modeled by the Freundlich equation. In general, much less molybdate than phosphate was sorbed by the soils. The capacity of the soils for sorbing molybdate and phosphate is related to their chemical properties. The increase in solution $\mathrm{pH}$, accompanying molybdate sorption, indicates that this anion are sorbed through ligand exchange with hydroxyl groups exposed at colloidal particle surfaces of the Andisols. 
Phosphate competes strongly with molybdate for sorption sites resulting in more molybdate concentration in soil solution, increasing Mo availability for plant production. Molybdenum deficiency in Andisols may therefore be overcome by maintaining its concentration in soil solution at adequate levels through phosphate fertilization.

\section{Acknowledgements}

This research was supported by the Comisión Nacional de Investigación Científica y Tecnológica, CONICYT and Fondo Nacional de Desarrollo Científico y Tecnológico, FONDECYT through the projects $\mathrm{N}^{\circ}$ 1100625 and MEC-CONICYT N ${ }^{\circ} 80100008$.

We are grateful to Dr. N.J. Barrow of Mt. Claremont, Australia for assistance in modelling competitive anion sorption by soils.

\section{References}

Barrow, N.J., 1970. Comparison of the adsorption of molybdate, sulfate and phosphate by soils. Soil Science 109, 282-288.

Barrow, N.J. 1985. Reactions of anions and cations with variable-charge soils. Advances in Agronomy 38, 183-230.

Barrow, N.J., 1992. The effects of time on the competition between anions for sorption. Journal of Soil Science 43, 421-428.

Barrow, N.J., 1999. The four laws of soil chemistry: the Leeper lecture 1998. Australian Journal of Soil Research 37, 787-829.

Barrow, N.J., Cartes, P., Mora, M.L., 2005. Modifications to the Freundlich equation to describe anion sorption over a large range and to describe competition between pairs of ions. European Journal of Soil Science 56, 601-606.
Bolan, N.S., Barrow, N.J., 1984. Modeling the effects of sorption of phosphate and other anions on the surface charge of variable charge oxides. Journal of Soil Science 35, 273-281.

Bolan, N.S., Syers, J.K., Tillman, R.W., 1986. Ionic strength effects on surface charge and sorption of phosphate and sulphate by soils. Journal of Soil Science 37, 379-388.

Edgell, K., 1988. USEPA Method Study 37 SW-846 Method 3050 Acid Digestion of Sediments, Sludges, and Soils. EPA Contract No. 68-03-3254. 34pp.

Giles, C.H., Smith, D., Huitson, A., 1974. A general treatment and classification of the solute adsorption isotherm. I. Theoretical. Journal of Colloid and Interface Science 47, 755-765.

Goldberg, S., Sposito, G., 1985. On the mechanism of specific phosphate adsorption by hydroxylated mineral surfaces: a review. Communications in Soil Science and Plant Analysis 16, 801-821.

Goldberg, S., Forster, H.S., 1998. Factors affecting molybdenum adsorption by soils and minerals. Soil Science 163, 109-114.

Goldberg, S., Scalera, E., Adamo, P., 2008. Molybdenum adsorption by volcanic Italian soils. Communications in Soil Science and Plant Analysis, 39, 693-706.

Goldberg, S., 2009. Influence of soil solution salinity on molybdenum adsorption by soils. Soil Science 174, 9-13.

Heilman, M.D., Carter, D.L., González, C.L., 1965. Ethylene glycol monoethyl ether for determining surface area of silicate minerals. Soil Science 100, 356-360.

Holtzclaw, K., Sposito, G., 1979. Analytical properties of the soluble, metal-complexing fractions in sludge-soil mixtures; III. Unaltered anionic sur- 
factants in fulvic acid. Soil Science Society of America Journal 43, 318-323.

Jara, A., Violante, A., Pigna, M., Mora, M.L., 2006. Mutual interaction of sulfate, oxalate, citrate and phosphate on synthetic and natural allophanes. Soil Science Society of America Journal. 70, 337-346.

López, R., Alvear, M., Gianfreda, L., Mora, M.L., 2007. Molybdenum availability in Andisols and its effect on biological parameters of soil and red clover (Trifolium pratense L.). Soil Science 172, 913-924.

Mora, M.L., Shene, C. Violante, A., Demanet, R. and Bolan N.S. 2005. The effect of organic matter and soil chemical properties on sulfate availability in chilean volcanic soils. In. Soil abiotic and biotic interactions and the impact on the ecosystem and human welfare, Huang, P.M., Violante, A., Bollag, J.M. and Vityakon P. (eds). ISBN 1-57808344-3; C. 444, Science Publishers, Inc.,New Hapshire, USA, Chapter 13. pp: 223-244.

Mora, M.L., Alfaro, M.A., Jarvis, S.C., Demanet, R., Cartes, P. 2006. Soil aluminum availability in Andisols of Southern Chile and its effect on forage production and animal metabolism. Soil Use and Management 22: 95-101.

Parfitt, R.L., 1989. Phosphate reactions with natural allophane, ferrhydrite and goethite. Journal of Soil Science 40, 359-369.

Ribera, A., Mora, M.L., Ghiselini, V., Demanet, R., Gallardo, F., 2010. Phosphorus-molybdenum relationship in soil and red clover (Trifolium pratense L.) on an acid Andisol. Journal of Soil Science and Plant Nutrition 10, 78-91.

Roy, W.R., Hazte, J.J., Griffin, R.A., 1986. Competitive interactions of phosphate and molybdate on arsenate adsorption. Soil Science 142, 203-210.
Sadzawka, A., Carrasco, M.A., Grez, R., Mora, M.L., Flores, H., Neaman, A., 2006. Métodos de análisis recomendados para los suelos chilenos. Serie Actas $\mathrm{N}^{\circ}$ 34. Instituto de Investigaciones Agropecuarias (INIA), Centro Regional de Investigación La Platina (INIA La Platina), Santiago, Chile. 164pp.

Soltanpour, P.N., 1991. Determination of nutrient availability and elemental toxicity by AB-DTPA soil test and ICPS. Advances in Soil Science 16, 165-190.

Theng, B.K.G., 1971. Adsorption of molybdate by some crystalline and amorphous soil clays. New Zealand Journal of Science 14, 1040-1056.

Theng, B.K.G., Yuan, G., Hashizume, H., 2005. Clay minerals and polymers: from soils to nanocomposites. Clay Science 12, Supplement 1, 69-73.

Vistoso, E.M. 2005. Factores que influencian la dinámica del molibdeno en el sistema sueloplanta en Andisoles del Sur de Chile. Tesis de Doctor en Ciencias de Recursos Naturales. Universidad de La Frontera, Facultad de Ingeniería Ciencias y Administración, Temuco, Chile. 128 p. Available in: http://rrnn.agroindustria.dm.cl/verp. php?id=170

Vistoso, E.M., Bolan, N.S., Theng, B.K.G., Mora, M.L., 2009. Kinetics of molybdate and phosphate sorption by some Chilean Andisols. Journal of Soil Science and Plant Nutrition 9, 55-68.

Xie, R.J., McKenzie, A.F., 1991. Molybdate sorptiondesorption in soils treated with phosphate. Geoderma 48, 321-333.

Xu, N, Cristodoulatos, C., Braida, W., 2006. Modeling the competitive effect of phosphate, sulfate, silicate and tungstate anions on the adsorption of molybdate onto goethite. Chemosphere 64, 1325-1333. 